\title{
项目管理中的招标采购及合同管理研究
}

\author{
刘禹江 \\ 贵州黔源电力股份有限公司 \\ DOI:10.32629/hwr.v4i9.3349
}

\begin{abstract}
[摘 要] 当前,我国水利水电行业发展迅速,并对项目管理提出了十分严格的要求。招标采购合同管理是 企业项目管理中的重要内容, 采取有效措施高度落实此项工作不仅能够提高工程建设效率, 也可严格把 控工程的成本投入,为企业创造更高的经济效益。本文就将分析项目管理中的招标采购及合同管理, 以供 参考。
\end{abstract}

[关键词] 项目管理; 招标采购; 合同管理

中图分类号：F715.4 文献标识码：A

现阶段, 水利水电行业内部竞争呈 现白热化趋势, 企业若想更好地应对激 烈的市场竞争, 就应该采取有效措施加 强项目管理, 特别要关注招标采购和合 同管理, 从而增强企业的市场竞争力, 促 进企业的稳定发展。

\section{1 招标采购的作用}

标采购的公开性较强, 招标采购全 面面向社会, 丰富了物资采购的来源, 加 大了市场挖掘的潜力。招标采购要求向 公众公布采购信息、采购宗旨和采购要 求, 让所有单位及个人均可参与此项活 动, 进而丰富采购途径。招标采购也可防 控企业采购过程中的腐败行为, 公开物 资采购过程中的多个程序, 加强监督与 管理工作的针对性。再者, 招标采购也做 到事后审计向提前预防的转化, 切实改 进工作质量。再者, 招标采购也可有效降 低供应成本和项目成本, 增大项目的经 济效益和社会效益。

\section{2 招标采购管理在项目管理中 的应用}

项目管理过程中, 招标采购管理尤 为重要, 为切实加强招标采购管理工作, 需建立科学有效的招标采购管理体系, 完善招标采购组织机构, 制定科学的招 标采购计划, 结合工程实际确定招标采 购方式, 同时选择资质优越的供应商, 不 断改善招标采购管理效率。

\section{1建立完备的招标采购管理体系}

根据水利水电工程项目建设的主要 特征, 创建完善的项目招标采购管理制 度, 优化采购管理的工作流程, 进而全面 规范项目招标采购, 促进项目招标采购 工作的顺利开展。建立项目前期招标采 购管理机制能够为各项工作的顺利推进 奠定坚实基础, 实现采购工作的制度化 和规范化建设, 这有利于采购人员顺利 完成各项采购工作。

2.2 创建专业的的招标采购组织 机构

目前, 工程项目采购工作任务量较 大, 集约化的项目采购、监制和物流团队 能够更加合理地应用现有人力资源, 调 动多个专业人员的主观能动性, 使各项 重要工作由专人负责, 次要工作也必须 按照规范标准完成, 在明确分工的基础 上, 也可积极协调物资采购队伍, 这也是 创建采购组织的重要基础。

2.3制定科学的招标采购计划

制定招标采购计划时, 先要全方位 考虑项目建设的要求和采购过程中所需 的时间, 制定更加科学和完善的招标采 购计划, 以此为基础确定年度招标采购 计划的总体目标。如需要采购, 则可制定 科学有效的采购计划。采购工作中, 工作 人员务必做好采购计划跟踪工切实完成 项目计划的主要内容。具体来说, 工作人 员需全方位结合市场的发展现状, 对项 目建设中需要应用的大型机械设备, 特
别是市场上不常见的大型设备, 制定更 为科学和完善的采购计划, 以满足工程 施工的规划和要求。

\section{4确定招标采购方式}

由于招标采购项目性质和市场环境 等多种因素的限制, 在采购招标的过程 中可采取邀请招标、议标和询价等多种 不同的处理方式。采用不同的采购方式 就会出现不同的采购结果, 故而务必合 理选择采购方式。

\section{5 选择优质供应商}

首先, 采购机构和工作人员应当全 面结合工程建设概况分析判断供应商, 作出合理的选择。同时基于公开招标方 式, 全方位了解供应商的社会信誉及自 身资质, 在多家供应商激烈竞争的基础 上, 有效降低采购成本, 选择最佳供应 商。在采购的过程中, 采购人员不得忽视 物资的质量, 在物资质量满足规定要求 后, 方可与供应商共同签订合同和协议。

其次, 在招投标过程中, 需科学组织 确定中标单位, 工作中基于企业采购制 度和采购流程完善发标、回标和开标等 不同工作内容, 也可邀请经验丰富的专 家加强评标工作的科学性与合理性, 以 选择最优的中标企业。

\section{3 完善合同管理的有效措施}

3.1合同管理的主要内容

项目招投标工作中, 合同管理占据 着十分重要的位置, 这涵盖项目合同风 
险评估、合同谈判及合同签订等内容。

(1) 项目合同风险评估

项目合同风险评估中, 项目风险管 理评估、进度要求、付款程序及划分合 同风险均是十分重要的内容。

(2) 招标文件审核

招标文件审核工作中, 必须高度重 视招投标文件的审核工作, 招标文件审 核中需要做好合同文件审查、技术文件 审查。业主可在投标文件中提供草拟合 同文件。日常工作中仔细检查合同文件 的主要内容是否足够清晰, 是否存在异 议, 在中标后也可有序开展合同谈判。再 者, 在日常工作中必须高度关注合同变 更, 这也是降低工程成本, 增大工程经济 效益的重要途径。技术文件审查中, 应高 度重视文件的有效性和完整性, 投标文 件中, 若无法满足项目成本要求, 就无法 有效落实投标报价。

(3) 合同谈判及签订

开标和评标后, 双方要就合同条款 的内容进行协商谈判, 最终签订合同。为 有效规避项目落实中产生严重的纠纷, 可在合同谈判前请相关部门审查合同草 案, 当事人及职能部门也需提出合理的 意见。在双方就所有合同条款达成一致 时, 方可签署合同, 且双方必须仔细检查 每一个签名页, 如非法定代表签订合同, 则要有法人授权。

\section{2 合同管理的有效措施}

3.2.1创建完善的合同执行保障体系

招标工作中, 创建内容完备的合同 条款, 落实质量保证体系具有不可忽视 的现实意义, 这是工程项目合同管理与 控制的重要途径, 也是推动各项工作有
序开展的基础和前提。

\subsection{2确定合同管理流程}

合同管理中涉及到诸多的内容, 这 就要求相关人员依据时间和既定的规范 要求, 加强各单位的协调与配合, 制定科 学有效的合同管理程序, 让管理人员能 够依据合同管理的核心要点及工作要求, 加强合同管理的有效性, 进而为项目合 同管理工作的有序开展奠定坚实基础。

3.2.3建立完善的合同文档系统

合同文档系统能够确保合同内容的 存储和合同条款的全面落实, 在应用合 同文档系统的过程中, 一方面可为一方 失约失信提供全索赔的依据, 另一方面 也能够有效维护合同双方的合法权益, 也可严格把控监督工程项目建设的进度 情况, 做好各环节的总结工作。

3.2.4重视合同交底, 落实目标管理, 确定合同责任

签订合同后, 合同双方必须严格按 照合同条款的规定做好各项工作, 履行 自身的责任和义务。项目管理人员应先 明确合同中的主要内容, 并加强合同交 底等工作, 且结合项目实际采取科学有 效的管理措施, 优化综合管理水平, 采取 科学的手段不断完善合同管理系统, 推 动工程项目的顺利开展, 以建设出高品 质的工程。

\subsection{5加强合同执行过程管理}

采取有效措施加强合同履行过程中 的管理与控制有着十分重要的现实意 义。为充分发挥合同管理的作用和价值, 工作人员需要采取有效措施密切合同双 方的沟通和交流, 同时合理利用科学先 进的信息技术完善信息管理, 使工作人
员能够严格按照合同的要求切实做好各 项工作, 增强工作的秩序性, 推动工程建 设的高校完成。

3.2.6完善合同争议及纠纷管理

水利水电工程建设周期较长, 故而 履行合同的时间也相对较长, 在水利水 电工程建设的过程中也会受到诸多因素 的影响而产生诸多的纠纷。出现纠纷后 也会涉及到索赔的问题。而索赔主体具 有双向性, 且引发索赔的原因相对复杂, 因此在工程建设和履行合同的过程中也 会出现诸多的风险因素。针对此种情况, 相关人员可采取有效措施加强风险识别, 规避一级风险, 这样不仅可以减少水利 水电工程中的风险因素, 也可控制合同 双方的损失, 维护双方的切身利益。

\section{4 结束语}

现如今, 我国水利水电行业发展水 平显著提高, 企业也应采取多种科学的 方法和手段高度落实项目管理工作, 在 日常工作中制定切实有效的招标采购方 案, 将招标采购合同管理作为管理工作 中的重点内容, 一方面要注重采购质量, 另一方面也需降低成本投入, 从而切实 保障企业的经济效益, 增强企业的市场 竞争力, 为企业长期、稳定发展奠定坚实 的基础。

\section{[参考文献]}

[1]李预.施工项目管理中的招标采购及 合同管理[J].建材与装饰,2018,(27):130-131.

[2]王咤.如何做好项目管理中的招标 采购及合同管理[J].门窗,2019,(1):107-108.

[3]周琳。探讨项目管理中的招 标采购及合同管理 [J]. 现代国企研究, 2019,154(04):118. 